\title{
PRINSIP DASAR METODOLOGI PENGAJARAN PENDIDIKAN AGAMA ISLAM
}

\author{
Penulis : Husin, M.Pd.
}

( Dosen Tetap Prodi PGMI STIQ Amuntai )

Email : hafizhihusinsungkar@gmail.com

\begin{abstract}
Abstrak
Pendidikan adalah investasi sumber daya manusia jangka panjang yang mempunyai nilai strategis bagi kelangsungan peradaban manusia di dunia. Oleh sebab itu, hampir semua negara menempatkan variabel pendidikan sebagai sesuatu yang penting dan utama dalam konteks pembangunan bangsa dan negara.

Salah satu komponen penting dalam pendidikan adalah guru. Guru dalam konteks pendidikan mempunyai peranan yang besar dan strategis. Gurulah yang langsung berhadapan dengan peserta didik untuk mentransfer ilmu pengetahuan dan teknologi sekaligus mendidik dengan nilai-nilai positif melalui bimbingan dan keteladanan.Oleh karena itu, sudah selayaknya guru mempunyai berbagai kompetensi yang berkaitan dengan tugas dan tanggung jawabnya. Salah satunya ialah mengenai metodologi pengajaran pembelajaran.

Sebagai seorang pendidik muslim sudah seharusnya mengetahui tentang metodologi pengajaran pendidikan dalam Islam. Pendidikan ke-islaman atau pendidikan agama Islam, yakni upaya mengajarkan ajaran agama Islam dan nilai-nilainya menjadi way of life (pandangan dan sikap hidup) seseorang. Untuk itu, hendaknya diterapkan metodologi pengajaran Pendidikan Agama Islam yang tepat dan baik dalam proses pembelajaran agar tercapai tujuan pendidikan Islam sebagaimana apa yang diharapkan.
\end{abstract}

Kata Kunci : Prinsif, Metodologi, Pengajaran, PAI

\section{A. Pendahuluan}

Pendidikan merupakan bagian yang tidak terpisahkan dari hidup dan kehidupan manusia. ${ }^{1}$ Hubungan dua variable, antara manusia dengan pendidikan diawali sebuah pertanyaan yang mendasar: “apakah manusia dapat dididik?”. Ataukah manusia dapat tumbuh dan berkembang sendiri tanpa melalui pendidikan? Lantas bagaimana cara mendidiknya? dan seterusnya.

Pertanyaan diatas telah lama menjadi bahan kajian para ahli pendidikan, bahkan sejak zaman Yunani kuno. Pendapat yang umum dikenal dalam pendidikan barat mengenai mungkin dan tidaknya manusia dididik, sehingga melahirkan tiga aliran filsafat pendidikan; nativisme ${ }^{2}$, empirisme $e^{3}$ dan konvergensi ${ }^{4}{ }^{5}$

${ }^{1}$ Prof. Dr. H. Jalaluddin, “Teologi Pendidikan”.(Jakarta; Raja Grafindo Persada, 2003), Hal : 67.

${ }^{2}$ Para penganut aliran nativisme berpandangan bahwa bayi itu lahir sudah dengan pembawaan baik dan pembawaan buruk. Oleh karena itu, hasil akhir pendidikan ditentukan oleh pembawaan yang sudah dibawa sejak lahir. Berdasarkan pandangan ini, maka keberhasilan pendidikan ditentukan oleh anak didik itu sendiri.

${ }^{3}$ Aliran empirisme, bertentangan dengan paham aliran nativisme. Empirisme (empiri = pengalaman), tidak mengakui adanya pembawaan atau potensi yang dibawa lahir manusia. Dengan kata lain bahwa manusia itu lahir dalam keadaan suci, tidak membawa apa-apa. Karena itu, aliran ini berpandangan bahwa hasil belajar peserta didik besar pengaruhnya pada faktor lingkungan.

${ }^{4}$ Aliran ini berpandangan bahwa perkembangan individu itu baik dasar (bakat, keturunan) maupun lingkungan, kedua-duanya memainkan peranan penting. Bakat sebagai kemungkinan atau disposisi telah ada pada masing-masing individu, yang kemudian karena pengaruh lingkungan yang sesuai dengan kebutuhan untuk perkembangannya, maka kemungkinan itu lalu menjadi kenyataan. 
Terlepas dari pembahasan tentang ketiga aliran filsafat tersebut, manusia secara alamiah pada dasaranya bersifat tumbuh dan berkembang. ${ }^{6}$ Pola perkembangan manusia dan alam semesta berlangsung di atas hukum alam yang ditetapkan Allah SWT (Sunnatullah).

Realitas perkembangan manusia juga tidak terlepas dari lingkungan (sosiokultural), sehingga metodologi pendidikan yang mengiringi manusia itu sendiri juga secara otomatis diperlukan adanya perkembangan sehingga sesuai dengan kebutuhannya.

Metodologi berarti ilmu tentang metode, sementara metode berarti cara kerja yang bersistem untuk memudahkan pelaksanaan suatu kegiatan guna mencapai tujuan yang ditentukan. ${ }^{7}$ Metodologi merupakan hal yang sangat penting dalam Pendidikan Agama Islam (PAI). Semakin baik metode yang digunakan, maka akan semakin efektif dan efisien pula pencapaian tujuannya. Dalam metode mengajar, faktor guru, siswa, bahan yang akan diajarkan, situasi, sarana, prasarana, serta fasilitas-fasilitas lainnya sangat besar pengaruhnya. Dengan banyaknya faktor-faktor yang mempengaruhi di dalam penggunaan suatu metode, maka disini seorang guru dituntut untuk menetapkan metode yang paling baik dan harus dipakai di dalam pembelajaran Pendidikan Agama Islam agar pembelajaran tersebut berhasil.

\section{B. Pengertian Metodologi Pengajaran Pendidikan Agama Islam}

Dalam kamus besar bahasa Indonesia, metodologi berarti ilmu tentang metode atau uraian tentang metode. ${ }^{8}$ Dan dalam bahasa Arab disebut minhaj, wasilah, kaifiyyah, dan thoriqoh, semuanya adalah sinonim, namun yang paling populer digunakan dalam dunia pendidikan Islam adalah thoriqoh, bentuk jama' dari thuruq yang berarti jalan atau cara yang harus ditempuh. Menurut M. Arifin, metodologi berasal dari dua kata yaitu metode dan logi. Adapun metode berasal dari dua kata yaitu meta (melalui) dan hodos (jalan atau cara), dan logi yang berasal dari bahasa Greek (Yunani) yaitu logos (akal atau ilmu), maka metodologi adalah ilmu pengetahuan tentang jalan atau cara yang harus dilalui untuk mencapai suatu tujuan. Dengan demikian, metodologi pendidikan adalah sesuatu ilmu pengetahuan tentang metode yang dipergunakan dalam pekerjaan mendidik. ${ }^{9}$ Hanya saja, Mahmud Yunus menambahkan baik dalam lingkungan perusahaan atau perniagaan, maupun dalam kupasan ilmu pengetahuan dan lainnya. ${ }^{10}$

\footnotetext{
${ }^{5}$ Prof. Dr. H. Jalaluddin, “Teologi Pendidikan”....,hal : 46.

${ }^{6}$ Prof. H. Muzayyin Arifin, M.Ed. "Filsafat Pendidikan Islam” (Jakarta; PT Bumi Aksara, 2009), hal : 12.

${ }^{7}$ Tim Dirjen Pembinaan PAI pada Sekolah Umum, Metodologi Pendidikan Agama Islam, (Jakarta : Depatemen Agama RI, 2001), h. 19.

${ }^{8}$ Tim Penyusun Kamus, Kamus Besar Indonesia, Cet. empat, (Jakarta: Balai Pustaka, 2007), H. 741.

${ }^{9}$ M. Arifin, Ilmu Pendidikan Islam; Suatu Tinjauan Teoritis dan Praktis berdasarkan Pendekatan Interdisipliner, cet. ke empat, (Jakarta : Bumi Aksara, 1996), H. 61.

${ }^{10}$ Armai Arief,Pengantar Ilmu dan Metodologi Pendidikan Islam,(Jakarta : Ciputat Press. 2000), H. 87.
} 
Dalam bahasa Inggris, metode di sebut method dan way, keduanya diartikan cara. Sebenarnya yang lebih layak diterjemahkan cara adalah kata way itu, bukan kata method. Karena metode istilah yang digunakan untuk mengungkapkan pengertian "cara yang paling tepat (efektif) dan cepat (efisien)" dalam melakukan sesuatu. ${ }^{11}$ Maka metodologi dalam pengertian ini adalah ilmu tentang metode yaitu ilmu yang mempelajari cara yang paling tepat (efektif) dan cepat (efisien) untuk mencapaian tujuan pembelajaran Pendidikan Agama Islam. Berdasarkan pengertian tersebut, maka dijumpai dalam buku metodologi pengajaran lebih banyak membahas bermacam-macam metode, seperti metode ceramah, tanya jawab, diskusi, demontrasi dan lain-lain.

Pengertian yang lebih luas tentang metodologi adalah pendapat Hasan Langgulung, yang menyatakan bahwa metodologi pengajaran ialah ilmu yang mempelajari segala hal yang akan membawa proses pengajaran bisa lebih efektif. Dengan kata lain metodologi ini menjawab pertanyaan how, what, dan who yaitu pertanyaan bagaimana mempelajari sesuatu (metode)?, apa yang harus dipelajari (ilmu)?, serta siapa yang mempelajari (peserta didik) dan siapa yang mengajarkan (guru)?. ${ }^{12}$ Pendapat yang semakna dengan di atas dikemukakan oleh Omar Mohmmad Al-Toumy Al-Syaibany yang menyatakan bahwa. ${ }^{13}$

"Metode mengajar bermakna segala segi kegiatan yang terarah yang dikerjakan oleh guru dalam rangka kemestian-kemestian mata pelajaran yang diajarkan, ciri-ciri perkembangan murid-muridnya, dan suasana alam sekitarnya dan tujuan menolong muridmuridnya untuk mencapai proses belajar yang diinginkan dan perubahan yang dikehendaki pada tingkah laku mereka. Selanjutnya menolong mereka memperoleh maklumat, pengetahuan, keterampilan, kebiasaan, sikap, minat dan nilai-nilai yang diinginkan.

Pendapat di atas diperkuat dengan fiman Allah dalam Q.S.An-Nahl /16:125, sebagai berikut :

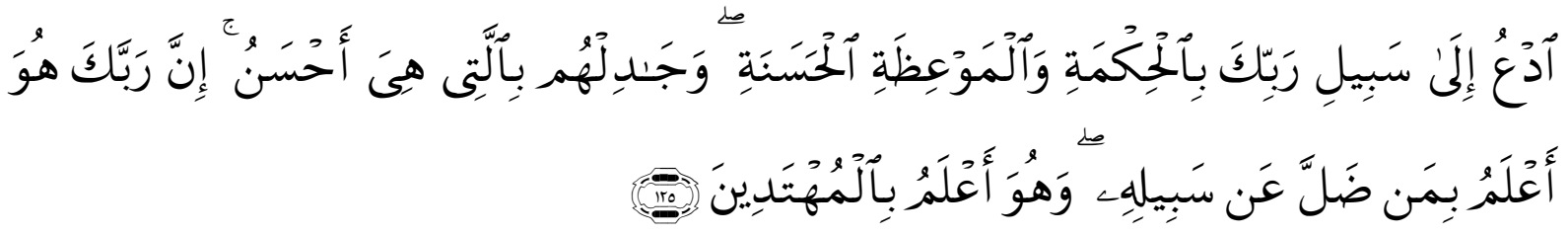

Artinya : Serulah (Manusia) kepada jalan Tuhanmu dengan bijaksana dan nasehat yang

\footnotetext{
${ }^{11}$ Ahmad Tafsir, Metodologi Pengajaran Agama Islam, Cet ke delapan, (Bandung : Remaja Rosdakarya, 2004), H. 9.

${ }^{12}$ Hasan Langgulung, Asas-asas Pendidikan Islam, edisi revisi, (Jakarta : Al-Husna Zikra, 2000), H. 350.

${ }^{13}$ Omar Mohammad Al-Toumy Al-Syaibany, Falsafah Pendidikan Islam, Alih bahasa Hasan Langgulung, cet. pertama. (Jakarta : Bulan Bintang, 1979), H. 553.
} 
baik, serta berbantahlah mereka dengan cara yang baik.

Adapun pengertian dari metodologi pengajaran agama Islam, Tayar Yusuf dan Syaiful Anwar berpendapat bahwa metodologi pengajaran agama Islam adalah "cara atau jalan yang ditempuh dalam menyajikan bahan-bahan pelajaran agama Islam agar mudah diterima, diserap dan dikuasai oleh anak didik dengan baik dan menyenangkan". ${ }^{14}$ Selain pendapat tersebut dalam buku Metodologi Pengajaran Agama Islam,Isfandi Muchtar mengemukakan metodologi pengajaran agama Islam yaitu "suatu upaya menetapkan kajian-kajian ilmiah tentang konsep-konsep dan fakta-fakta belajar mengajar dalam situasi kegiatan perencanaan, penerapan dan penilaian sistem pembelajaran agama Islam dalam rangka peningkatan proses dan hasil belajar yang optimal". ${ }^{15}$

Kemudian Ahmad Tafsir mengartikan metodologi pengajaran agama Islam adalah “cara yang paling tepat dan cepat dalam mengajarkan agama Islam. Kata cepat dan tepat ini sering diungkapkan sebagai efektif dan efesien. Kalau begitu metodologi pengajaran agama Islam adalah cara yang paling efektif dan efesien dalam mengajarkan agama Islam" ${ }^{16}$

Pada dasarnya baik apa yang didefinisikan oleh Ahmad Tafsir maupun oleh tokoh pendidikan yang lain, adanya kesamaan pemahaman bahwa metodologi pengajaran menginginkan agar bahan pelajaran dapat diterima anak didik dengan cara yang menyenangkan. Meskipun ada perbedaan dalam redaksi kalimat, tetapi tidaklah berseberangan dalam pengertian sebenarnya.

\section{Tujuan Metodologi Pendidikan Agama Islam}

Ramayulis dalam bukunya Metodologi Pengajaran Agama Islam mencantumkan bahwa metodologi pengajaran dalam pendidikan Islam bertujuan:

1. Menolong pelajar untuk mengembangkan pengetahuan, maklumat, pengalaman, keterampilan dan sikapnya, terutama keterampilan berpikir ilmiah yang betul dan sikap dalam bentuk cinta ilmu, suka menuntutnya dan membuka rahasianya, dan merasa enak dan nikmat dalam mencarinya.

2. Membiasakan pelajar mengahafal, memahami, berpikiran sehat, memperhatikan dengan tepat, mengamati dengan tepat, rajin, sabar dan teliti dalam menuntut ilmu, mempunyai pendapat yang berani, asli dan bebas.

\footnotetext{
${ }^{14}$ Tayar Yusuf dan Syaiful Anwar, Metodologi Pengajaran Agama dan Bahasa Arab, (Jakarta: Raja Grafindo Persada, 1995), h. 2.

${ }^{15}$ Isfandi Muchtar, Metodologi Pengajaran Agama Islam; PBM-PAI di Sekolah Eksistensi dan Proses Belajar Mengajar Pendidikan Agama Islam, (Yogyakarta: Pustaka Pelajar, 1998), h. 144.

${ }^{16}$ Ahmad Tafsir, Metodologi Pengajaran Agama Islam..., h. 9.
} 
3. Menciptakan suasana yang sesuai bagi pengajaran yang berlaku, sifat percayamempercayai dan hormat-menghormati antara guru dan murid dan hubungan baik antara keduanya, dan juga meningkatkan semangat pelajar dan menggalakkannya belajar dan bergerak.

4. Memudahkan proses pengajaran itu bagi pelajar dan membuatnya mencapai sebanyak mungkin tujuan yang diinginkan dan menghemat tenaga dan waktu yang diperlukan untuk mencapainya. ${ }^{17}$

Selain itu Basyiruddin Usman dalam bukunya Metodologi Pembelajaran Agama

Islam memaparkan bahwa metodologi pengajaran agama Islam sangat bermanfaat bagi para guru atau pendidik agama Islam, karena:

1. Membahas tentang berbagai prinsip, teknik-teknik dan pendekatan pengajaran yang digunakan. Dengan mempelajarinya seorang guru dapat memilih metode manakah yang layak dipakai, mempertimbangkan keunggulan dan kelemahannya serta kesesuaian metode tersebut dengan karakteristik siswa dan ciri-ciri khas materi yang akan disajikan sehingga kegiatan belajar mengajar dapat berlangsung secara optimal untuk mencapai tujuan yang ditetapkan.

2. Terlalu luasnya materi pelajaran agama Islam dan sedikitnya waktu yang tersedia untuk menyampaikan bahan, sudah barang tentu memerlukan pemikiran yang mendalam bagaimana usaha guru agama, agar tujuan pengajaran dan pendidikan agama Islam dapat tercapai dengan sebaik-baiknya. Disinilah fungsi metodologi pengajaran agama Islam dapat memberi makna yang besar sekali terhadap guru yang telah mempelajarinya secara baik, terutama yang berkenaan dengan desain dan rancangan pengajaran.

3. Sifat pengajaran agama Islam lebih banyak menekankan pada segi tujuan afektif (sikap) dibanding tujuan kognitif, menjadikan peranan guru agama Islam lebih bersifat mendidik dari pada mengajar. Metodologi pengajaran agama Islam turut memberikan distribusi pengetahuan terhadap mahasiswa sebagai calon guru atau pendidik yang diharapkan. ${ }^{18}$

\section{Prinsip-Prinsip Metodologi Pengajaran Pendidikan Agama Islam}

Prinsip disebut juga dengan asas atau dasar. Asas adalah kebenaran yang menjadi pokok dasar berfikir, bertindak dan sebagainya. Dalam hubungannya dengan metodologi pendidikan Islam berarti prinsip yang dimaksud disini adalah dasar pemikiran yang digunakan dalam mengaplikasikan metode pendidikan Islam.

\footnotetext{
${ }^{17}$ Ramayulis, Metodologis Pengajaran Agama Islam,Cet.III (Jakarta: Kalam Mulia, 2001), h. 110.

${ }^{18}$ Basyiruddin Usman, Metodologi Pembelajaran Agama Islam, (Jakarta: Ciputat Pers, 2002), h. 6.
} 
Prinsip-prinsip pelaksanaan metodologi pendidikan Islam menurut Omar Muhammad Al-Toumy Al-Saibany adalah sebagai berikut : ${ }^{19}$

1. Mengetahui motivasi, keperluan dan minat anak didiknya.

2. Mengetahui tujuan pendidikan yang sudah ditetapkan sebelum pelaksanaan pendidikan.

3. Mengetahui tahap kematangan, perkembangan, serta perubahan tingkah laku anak didik.

4. Mengetahui perbedaan-perbedaan individu di dalam anak didik.

5. Memperhatikan kepahaman, dan mengetahui hubungan-hubungan, integrasi pengalaman dan kelanjutannya, keaslian, pembaharuan dan kebebasan berfikir.

6. Menjadikan proses pendidikan sebagai pengalaman yang menggembirakan bagi anak didik.

7. Menegakkan "uswah hasanah"

Hasan Langgulung mengemukakan adanya tiga prinsip yang mendasari metode mengajar dalam Islam, yaitu :

1. Sifat-sifat metode dan kepentingan yang berkenaan dengan tujuan utama pendidikan Islam, yaitu pembinaan manusia mukmin yang mengaku sebagai hamba Allah.

2. Berkenaan dengan metode mengajar yang prinsip-prinsipnya terdapat dalam Al-Qur'an atau disimpulkan dari padanya.

3. Membangkitkan motivasi dan adanya kedisiplinan atau dalam istilah Al-Qur'an disebut ganjaran dan hukuman.

Sedangkan pendidikan modern yang diterapkan di negara-negara maju seperti negaranegara Barat yang mana didasarkan kepada teori mengajar modern yaitu : teaching is the guidance of learning. Mengajar adalah bimbingan kepada anak dalam proses belajar. ${ }^{20}$

Adapun Zakiah Daradjat mengemukakan tentang prinsip-prinsip metodologi pengajaran agama Islam sebagai berikut :

\section{Individualitas}

Yang dimaksud Zakiah Daradjat dengan individu disini adalah "pribadi atau jiwa sendiri. Kekhususan jiwa itu menyebabkan individu yang satu berbeda dengan individu yang lain. Dengan perkataan lain, tiap-tiap manusia mempunyai jiwa sendiri”, ${ }^{21}$

\section{Kebebasan}

\footnotetext{
${ }^{19}$ Dr. Armai Arief, MA, Pengantar Ilmu dan Metodologi Pendidikan Islam, (Jakarta: Ciputat Pers, 2002), h. 93-94

${ }^{20}$ Ramayulis, Metodologis Pengajaran Agama Islam,Cet.III..., hal 106.

${ }^{21}$ Zakiah Daradjat, dkk, Metodik Khusus Pengajaran Agama Islam, cet.VI (Jakarta: Bumi Aksara, 2014), h. 118.
} 
Kebebasan yang dimaksud Zakiah Daradjat disini bukanlah sebuah kebebasan yang sebebas-bebas atau tanpa batasan, melainkan kebebasan yang terukur dan berdasar pada nilai-nilai yang dianut di masyarakat. Kebebasan yang diinginkan adalah adanya kesempatan dari guru untuk memberikan kepada siswa untuk dapat mengembangkan diri dalam proses pengajaran.

\section{Lingkungan}

Dari hasil penyelidikan yang dilakukan oleh para ahli psikologi diperoleh petunjuk bahwa "faktor lingkungan berpengaruh dalam hal pembentukan kebiasaan, kepribadian dan nilainilai seorang anak". ${ }^{22}$ Jadi seorang guru harus mengatur lingkungan sebaik-baiknya, sehingga terciptalah suasana yang baik dan menjauhkan pengaruh yang buruk.

\section{Globalisasi}

Prinsip globalisasi dalam pengajaran menurut Zakiah Daradjat “...menekankan bahwa keseluruhan pengamatan harus menjadi titik permulaan pengajaran. Seorang anak biasanya mengamati keseluruhan lebih dahulu baru kemudian bagian-bagiannya". ${ }^{23}$

\section{Pusat-pusat Minat}

Bila murid telah berminat terhadap kegiatan belajar-mengajar, maka hampir dapat dipastikan proses pengajaran itu akan berjalan dengan baik dan hasil belajar akan optimal. Bila minat telah muncul maka perhatian pasti akan mengikutinya, tetapi sama dengan minat, perhatian mudah sekali berkurang atau menghilang.

\section{Aktivitas}

Dalam pengajaran agama menurut Zakiah Daradjat prinsip aktvitas ini dapat dilaksanakan seperti halnya pelajaran lain. Yang harus diingat ialah pada waktu guru mengajar, ia harus memberi kesempatan kepada murid agar mereka aktif rohani maupun jasmani, secara perseorangan ataupun secara bersama.

\section{Motivasi}

Menurut Zakiah Daradjat motivasi dalam pengajaran adalah “...usaha yang disadari oleh pihak guru untuk menimbulkan motif-motif pada diri murid yang menunjang kegiatan ke arah tujuan-tujuan belajar dan menciptakan kondisi sedemikian rupa sehingga anak itu mau melakukan apa yang dapat dilakukannya". ${ }^{24}$

\footnotetext{
${ }^{22}$ Zakiah Daradjat, dkk, Metodik Khusus Pengajaran Agama Islam..., h. 129.

${ }^{23}$ Zakiah Daradjat, dkk, Metodik Khusus Pengajaran Agama Islam...., h. 132.

${ }^{24}$ Zakiah Daradjat, dkk, Metodik Khusus Pengajaran Agama Islam...., h. 140.
} 


\section{Pengajaran Berupa}

Dalam pengajaran berupa diusahakan agar murid mengamati sesuatu dengan teliti dan penuh perhatian. Dengan kata lain dalam pengajaran berupa anak-anak memperoleh pengetahuan yang baru terutama dengan pertolongan inderanya karena apa yang kita peroleh seperti pengetahuan, tanggapan-tanggapan, pengertian-pengertian dan sebagainya, masuk ke dalam jiwa kita melalui indera. Pengamatan kita lakukan dengan bantuan indra.

\section{Korelasi dan Konsentrasi}

Yang dimaksud dengan korelasi disini adalah hubungan antara satu mata pelajaran dengan mata pelajaran lain yang berfungsi dapat menambah kematangan pengetahuan yang dimiliki siswa.

Adapun prinsip-prinsip metode pengajaran menurut Tayar Yusuf dan Syaiful Anwar terdiri dari prinsip apersepsi, motivasi, perhatian, individualitas, aktivitas, korelasi dan konsentrasi, serta peragaan/media pengajaran. Mereka memasukkan apersepsi sebagai salah satu prinsip dalam metode pengajaran. Apersepsi disini diartikan sebagai "aktivitas guru memberikan rangsangan perhatian dan kesadaran kepada anak didik agar dapat memperhatikan pelajaran yang akan diberikan itu secara sungguh-sungguh, tidak mainmain". 25

\section{E. Prinsip Dasar Metodologi Pendidikan Islam secara Historis, Filosofis dan Teoritis}

\section{Historis}

Nilai-nilai historis yang kemudian dijadikan sebadai landasan historis pendidikan, memiliki makna bahwa peristiwa kemanusiaan yang terjadi di masa lampau penuh dengan informasi-informasi yang mengandung kejadian-kejadian, model-model, konsep-konsep, teori-teori, praktik-praktik, moral, cita-cita, bentuk, dan sebagainya. Informasi dari sebuah peristiwa dimasa lampau tersebut mengandung muatan nilai pendidikan yang dapat dicontohkan dan ditiru oleh generasi masa kini dan yang akan datang. ${ }^{26}$

Nilai-nilai yang terkandung dalam sejarah tersebut adakalanya positif, sehingga bisa dijadikan bahan acuan dalam pelaksaan pendidikan dimasa kini jika masih relevan dan mengembangkan serta menelitinya ketika tidak relevan. Dan adakalanya yang negatif, dalam hal ini cukup dijadikan pelajaran agar tidak diikuti baik oleh generasi sekarang atau dimasa yang akan.

\footnotetext{
${ }^{25}$ Tayar Yusuf dan Syaiful Anwar, Metodologi Pengajaran Agama dan Bahasa Arab..., h. 96.

${ }^{26}$ A. Fatah Yasin, Dimensi-dimensi Pendidikan Islam, (Malang; UIN-Malang Press, 2008), h 32.
} 


\section{Filsafat dan Teoritis}

Apabila kita berbicara mengenai nilai-nilai, maka filsafat perlu dipertimbangkan agar pilihan kita menjadi bijaksana. Hal yang demikian berlaku pula pada metode pendidikan, karena ia menyangkut pembentukan kepribadian manusia dan kualitas hidup mereka.

Bagaimana hubungan pemilihan metode tersangkut dengan masalah filsafat dapat dilihat pada uraian berikut :

a. Marilah kita lihat dari titik pandangan pembentukan karakter yang berlangsung di dalam diri setiap anak. Belajar adalah suatu bagian terpaut pada pengalaman kehidupan yang secara berkumulatif menyerap ke dalam sifat-sifat karakter. Karakter spesifik yang terbangun akan tergantung pada jenis tanggapan pelajar yang membuat situasi kehidupan yang ditemuinya. Umpamanya tanggapan anak terhadap suatu otoritas pada dirinya mempunyai makna yang berkesan. Satu jenis perlakuan orang tua atau guru akan mempengaruhi anak, ada yang berupa perlawanan, atau penurutan - kepatuhan, atau akan mendorongnya menjadi aktif. Berbagai kemungkinan ini adalah suatu kemelut bagi masalah metode.

b. Ada banyak jalan untuk mengurus sekolah dan cara mengajar murid. Setiap perbedaan cara mengajar itu mempengaruhi tipe korelasi tanggapan murid dan sesuai dengan tipe korelasi itu menghasilkan sifat-sifat karakter. Kemungkinan-kemungkinan perbedaan pengaruh karakter itu menuntut adanya pemilihan metode yang teliti.

c. Pertimbangan-pertimbangan mengenai masyarakat sekolah yang akan dipersiapkan, umpamanya masyarakat demokratis atau yang lain. Perbedaan jenis masyarakat tersebut.

Masalah metode ini dapat dilihat secara sempit dan dapat pula secara luas. Secara sempit ia hanya menyangkut mata pelajaran yang akan diajarkan dan bagaimana mengelola tipe mengajar yang terbatas. Tetapi secara luas masalah metode ini menyangkut dengan banyak nilai yang akan ditegakkan, seperti nilai mata pelajaran, sikap dan karakter yang akan dibangun, pengaruh kehidupan demokrasi, nilai-nilai masyarakat, dan semua masalah yang berkaitan dengan situasi khusus. Bagaimana berbuat dengan anak menyangkut nilai-nilai tersebut tadi, sebenarnya berfilsafat. Di situ kita menimbang -nimbang nilai yang akan dipegang dan mencari mana yang lebih dalam yang patut diikuti.

Kalau kita kembali kepada pandangan secara sempit, maka timbul pula permasalahan kesatuan mata pelajaran dengan metode. Menurut paham dualisme, jiwa dan dunia benda termasuk orang adalah dua yang terpisah dan mempunyai alam yang berdiri sendiri, dan pandangan ini pun mengganggap bahwa metode dan mata pelajaran terpisah. Mata pelajaran adalah suatu klasifikasi fakta yang secara sistematis sudah siap. Metode mempunyai 
daerahnya sendiri yang akan menyampaikan mata pelajaran secara baik dan berkesan di dalam jiwa. Secara teori, suatu ilmu dapat dideduksikan ke dalam jiwa dengan melalui metode yang lengkap.

Tetapi oleh karena pikiran itu adalah suatu gerak yang terarah dari mata pelajaran menuju kepada penyempurnaan peristiwa, dan karena jiwa adalah fase intensi proses, pendapat yang memecah antara metode dengan mata pelajaran itu adalah keliru. Kenyataannya bahan suatu ilmu pengetahuan yang terorganisasi itu adalah bukti bahwa ia terlah tersedia di mata pelajaran bagi intelegensi, itu adalah dimetodikkan. Dengan kata lain metode itu berarti suatu rangkaian mata pelajaran yang membuatnya sangat efektif dalam penggunaan. Jadi metode itu tak pernah berada di luar bahan pelajaran. Metode tidak bertentangan dengan mata pelajaran, ia adalah pengarahan yang efektif bagi mata pelajaran menuju hasil yang dihasratkan. ${ }^{27}$

\section{F. Metodologi Pengajaran PAI menurut Ali Kholil Abul ‘Ainain}

Ali Kholil Abul 'Ainain di dalam kitabnya: Falsafatul Tarbiyatul Islam Fil Quranil Karim mengemukakan secara panjang lebar tentang metode pendidikan Islam ini yang ringkasnya ada 11 macam yaitu:

1. Pengajaran tentang cara beramal dan pengajaran/keterampilan. Metode ini dapat dilakukan melalui ibadah shalat, zakat, puasa, haji dan jihad.

2. Mempergunakan akal.

3. Contoh yang baik dan jujur.

4. Perintah kepada kebaikan, larangan perbuatan munkar saling berwasiat kebenaran, kesabaran dan kasih sayang.

5. Nasihat-nasihat.

6. Metode kisah.

7. Tamsil.

8. Menggemarkan dan menakutkan atau dorongan dan ancaman.

9. Menanamkan atau menghilangkan kebiasaan.

10. Menyalurkan bakat.

11. Peristiwa-peristiwa yang berlalu.

Dari uraian di atas dapat disimpulkan bahwa para ahli Islam telah sepakat tentang pentingnya metode pendidikan, namun mereka masih berbeda pendapat mengenai berapa macam metode tersebut untuk dipakai mendidik anak agar menjadi manusia yang takwa

\footnotetext{
${ }^{27}$ Zakiah Daradjat, dkk, Metodik Khusus Pengajaran Agama Islam..., h 58-59.
} 
kepada Allah atau berkepribadian muslim. Pondok pesantren yang merupakan lembaga pendidikan Islam formal tertua di Indonesia, menggunakan dua macam metode yang terkenal yaitu:

a. Sorogan atau sering kali disebut bandongan yaitu penyampaian pelajaran dimana seorang santri atau murid maju dengan membawa kitab untuk dibaca dihadapan seorang guru atau kyai. Selanjutnya kyai itu membimbing kepada santri apabila ia menemui kesulitan dan membetulkan apabila ia melakukan kekeliruan.

b. Wetonan ialah penyampaian pelajaran dimana seorang guru atau kyai membacakan kitab, menterjemahkan, menerangkan dan sering kali mengulas buku-buku dihadapan sekelompok murid atau santri.

Kedua metode tersebut sampai saat ini masih diinginkan oleh hampir seluruh pondok pesantren yang ada di negeri kita. Selanjutnya apabila diperhatikan lebih jauh khususnya mengenai metode Sorogan ternyata metode ini membawa konsekuensi pelayanan yang sebenar-benarnya kepada santri secara individual. Sedangkan pelayanan secara individual kepada murid itu menjadi perhatian bagi ahli-ahli didik sekarang ini.

Sebagaimana kita ketahui dewasa ini, dikembangkan belajar sistem mandiri di bawah asuhan guru/dosen, metode ini merupakan salah satu metode belajar dalam sistem kredit. Kiranya tidak berlebih-lebihan jika dikatakan ada persamaan antara sistem Sorogan dan sistem belajar mandiri tersebut, namun juga diakui adanya perbedaan tertentu. ${ }^{28}$

Sedangkan menurut Drs. H. M. Arifin M.Ed, bahwa dalam Al Quran dan sunnah Nabi dapat ditemukan metode-metode untuk pendidikan agama itu antara lain:

1. Perintah/Larangan

2. Cerita tentang orang-orang yang taat dan orang-orang yang berdosa (kotor) dan linlain serta akibat-akibat pebuatan meraka.

3. Peragaan

4. Instruksional

5. Acquisition (self=education)

6. Mutual Education (mengajar dalam kelompok)

7. Exposition (dengan menyajikan) yang didahului dengan motivation (menimbulkan minat)

8. Function (pelajaran dihidupkan dengan praktek)

\footnotetext{
${ }^{28}$ Dra. Hj. Nur Uhbiyati, Ilmu Pendidikan......, hal. 204-205.
} 
9. Explanation (memberikan penjelasan tentang hal-hal yang kurang jelas). ${ }^{29}$

Adapun metode pendidikan yang dikemukakan Ustadz Muhammad Said Ramadhan Al-Buthi dalam bukunya yang berjudul Al-Manhajud Tarbawi Faried fil Quran, menyatakan bahwa ada tiga macam akses atau dasar yang dipakai Al-Quran untuk menananmkan pendidikan yaitu:

1. Muhakammah Aqliyah, yaitu mengetuk akal pikiran untuk memecahkan segala sesuatu.

2. Al-Qisas Wat Tarikh, yaitu menggunakan cerita-cerita dan pengetahuan sejarah.

3. Al-Itsarah Al-Wijdaniyah, yaitu memberikan perangsang kepada perasaan-perasaan. ${ }^{30}$ Menurut Muhammad Qutb di dalam bukunya Minhajut Tarbiyah Islamiyah menyatakan bahwa teknik metode pendidikan Islam itu ada delapan macam yaitu, pendidikan melalui teladan, pendidikan melalui nasihat, pendidikan melalui hukuman, pendidikan melalui cerita, pendidikan melalui kebiasan, menyalurkan kekuatan, mengisi kekosongan, pendidikan melalui peristiwa-peristiwa. ${ }^{31}$

\section{F. Simpulan}

Metodologi pengajaran ialah ilmu yang mempelajari segala hal yang akan membawa proses pengajaran bisa lebih efektif. Ada berbagai pendapat tentang metodologi pengajaran pendidikan agama Islam salah satunya adalah pendapat Ahmad Tafsir mengartikan metodologi pengajaran agama Islam adalah "cara yang paling tepat dan cepat dalam mengajarkan agama Islam. Dari berbagai pendapat tersebut dapat disimpulkan bahwa metodologi pengajaran pendidikan agama Islam adalah ilmu yang membahas tentang penggunaaan cara memberikan bahan pelajaran agama Islam secara efektif dan efesien.

Ada berbagai pendapat dari pakar pendidikan tentang tujuan metodologi pengajaran pendidikan agama Islam, diantaranya Zakiah Daradjat mengemukakan tujuan metodologi pengajaran agama Islam adalah menyampaikan bahan pelajaran agama Islam kepada anak didik dengan pengajaran yang menyenangkan dan berarti bagi anak didik agar bahan pelajaran itu dapat diterima dan dicernakan oleh anak didik.

Ada berbagai pendapat tentang prinsip-prinsip metodologi pengajaran pendidikan agama Islam, diantaranya adalah pendapat Omar Muhammad Al-Toumy Al-Saibany yang mengemukakan 7 prinsip tentang metodologi pengajaran pendidikan agama Islam. Dan masih banyak lagi prinsip-prinsip yang dikemukakan oleh pakar pendidikan tentang prinsip-prinsip

\footnotetext{
${ }^{29}$ Dra. Hj. Nur Uhbiyati, Ilmu Pendidikan......, hal. 205-207.

${ }^{30}$ Dra. Hj. Nur Uhbiyati, Ilmu Pendidikan........ hal. 195-196.

${ }^{31}$ Dra. Hj. Nur Uhbiyati, Ilmu Pendidikan......, hal. 197-203.
} 
metodologi pengajaran pendidikan agama Islam dan inti dari semua prinsip-prinsip itu sama walaupun redaksi kalimatnya berbeda. 


\section{DAFTAR PUSTAKA}

Al-Syaibany, Omar Mohammad Al-Toumy. Falsafah Pendidikan Islam, Alih bahasa Hasan Langgulung, cet. pertama. Jakarta. Bulan Bintang. 1979.

Arief, Armai. Pengantar Ilmu dan Metodologi Pendidikan Islam. Jakarta. Ciputat Press. 2000.

Arief, Armai. Pengantar Ilmu dan Metodologi Pendidikan Islam. Jakarta. Ciputat Pers. 2002.

Arifin, Muhammad. Ilmu Pendidikan Islam; Suatu Tinjauan Teoritis dan Praktis berdasarkan Pendekatan Interdisipliner, cet. ke empat. Jakarta. Bumi Aksara. 1996.

Arifin, Muzayyin. Filsafat Pendidikan Islam. Jakarta. PT Bumi Aksara. 2009.

Daradjat, Zakiah. Metodik Khusus Pengajaran Agama Islam, cet.VI. Jakarta. Bumi Aksara. 2014.

Jalaluddin. Teologi Pendidikan. Jakarta. Raja Grafindo Persada. 2003.

Langgulung, Hasan. Asas-asas Pendidikan Islam, edisi revisi. Jakarta. Al-Husna Zikra. 2000.

Muchtar, Isfandi. Metodologi Pengajaran Agama Islam. PBM-PAI di Sekolah Eksistensi dan Proses Belajar Mengajar Pendidikan Agama Islam.Yogyakarta. Pustaka Pelajar. 1998.

Ramayulis. Metodologis Pengajaran Agama Islam,Cet.III. Jakarta. Kalam Mulia. 2001.

Tafsir, Ahmad. Metodologi Pengajaran Agama Islam, Cet ke delapan. Bandung. Remaja Rosdakarya. 2004.

Tim Dirjen Pembinaan PAI pada Sekolah Umum. Metodologi Pendidikan Agama Islam. Jakarta. Depatemen Agama RI. 2001.

Tim Penyusun Kamus. Kamus Besar Indonesia, Cet. Empat. Jakarta. Balai Pustaka. 2007.

Usman, Basyiruddin. Metodologi Pembelajaran Agama Islam. Jakarta. Ciputat Pers. 2002.

Yasin, A. Fatah. Dimensi-dimensi Pendidikan Islam. Malang. UIN-Malang Press. 2008.

Yusuf, Tayar dan Anwar, Syaiful. Metodologi Pengajaran Agama dan Bahasa Arab. Jakarta. Raja Grafindo Persada. 1995. 